\title{
The Italian Policy Towards the Albania Question". 1900-1912
}

\section{Niko Ferro}

Accademia di Belle Arti di Brera Milano, Italy

Email:ferroniko@hotmail.com

\section{Doi: $10.5901 / m j s s .2013 . v 4 n 4 p 291$}

\begin{abstract}
This paper aims to analyze the "Italian policy towards Albania" during the years 1900 -1911. Albanian issue and the role of the Great Powers. Italy and the Balkan War. The attitude of the Balkan States toward Albania. Status quo and the Austro Hungarian Empire.
\end{abstract}

Key words: Albania, the tripartite alliance, the Balkan War, Italia, Austro Hungarian, Turkey etc.

\section{The decline of the Ottoman Empire}

The Ottoman Empire's decline highlights the national question in the Balkans, but Europe should see the division of spheres of influence and protective of "balance of power". In this regard it is appropriate to establish a balance between the national question in the Balkans and "European intervention." In other words, it should be clarified that it was the external role; Balkan exterior factor is the development of the situation on the peninsula, a process that runs in parallel liberators with the fall of the Ottoman Empire. ( Puto 1987.fq 81) European intervention Balkan factor just to fill the void left behind by the Ottoman Empire cannot be denied. But it is not the only one. The dynamics of evolution of the situation on the peninsula is determined by the combination and interaction of two factors: "European" and "Local level". There is obviously interdependence between them, but the local factor, is the event engine is one that exerts a constant pressure on European diplomacy forcing it to turn back "Eastern Question". After the 19TH century, Eastern crisis in Europe was put some temporary political stability. Because of their interests, the Great Powers were inclined to maintain status quo for some time in the Ottoman Empire and the political map in the Balkans, where it was decided by the Congress of Berlin. Under these circumstances none of the Great Powers, at that time had not supported the idea of creating autonomous or independent Albanian State. They not only looked favorably on the Albanian liberation movement but were willing to help the Ottoman Empire to crush any internal armed rebellion. Great damage that caused the Albanian people for the war of national liberation has been the attitude of the neighboring countries, which were against the creation of the Albanian state. In January 1880, in an article published in the Ottoman "Istanbul" (Mile 1986) was written about the expansionist goals of the Great Powers on the Western Balkans Bosnia and Herzegovina became offspring [excuse] of the Russo-Turkish war and was taken seriously only at the time of the Russian intervention [1877-1878]. Austria is more attentive to what is happening or better for what might happen in the Balkan Peninsula, feels the need to change his personality, such as consular, as in Albania, as well as "Rushçuk" and Adrianople in Austro-Hungarian stationary there are a necessity for people with special ability. Italy that attitude through his emissaries, gives the "heart" of Albanian-Montenegrin resistance to restore. It is not necessary to demonstrate that the Government of Rome in the presence of the political Union of the two German powers and objectives Central Berlin dream vapor to open an aspiration at the expense of Vienna, is aware of the geographical scope of Germanisation in the future. That's not what will restore Trieste as German land but in Berlin. Farewell then those patriotic dreams Tyrol union and eastern shores of the Adriatic in Italy. Well today hostile principles voltage almost reached the maximum or nearly imprudence could put gun fire and see hearth concern is adjacent switches explosive elements of European policy. Exactly this gap may arise those complications that presage around the world and that, unless we care, the Albanian-Montenegrin (AMAE.CP Embassy of France in Istanbul. Volume 434 .fl $177 \mathrm{r} 178$ rv) issue may be the starting point. If between Albania and its neighbors are not restored peace, the movement of the dissolution of the Ottoman Empire in Europe will resume in the near Albania. Therefore powers who want to keep the peace, within a few months to find a choice of any two enforcement provisions of the Treaty of Berlin (AMAE. CP Embassy of France in Istanbul . Volume 434 fl 155-167 rv). While the Vienna government was acting skills, was fanning detestation between Albanians Montenegrins and reduce conflict in a war between these two neighboring peoples, so that they weaken each other, the Albanians, who were more numerous 
tiring and Montenegrins and remove undercut Russia so one of the causes of action that affect more against the Austro Hungarian-policy plans among the Slavs of Turkey. (AMAE CD Embassy of Frances. Istanbul Volume $435 \mathrm{fl} 130 \mathrm{rv}$ 137rv). Policies of the Great Powers to Albania was determined by their political and economic interests in the area and strategic position of the Albanian territories through which they pass trade routes, as well as a possible expansion of these Great Powers eastwards in Southwards Balkan depth in Thessaloniki on the Aegean Sea in the Mediterranean and in Africa. Austro-Hungary in turn, sought to sow up a good portion of the Balkan territories of the Ottoman Empire, including the Monastir and went to Thessaloniki, but this cannot be achieved without confrontation with Russia, which would join the Balkan Slavic states and end with the strengthening of Russia's positions in European Turkey. In these circumstances, Austro-Hungary was under pressure from Germany, who did not want conflict in the Middle East, followed conserver policy of status quo in the Ottoman Empire. It try to ensure economic and political superiority in Albania and Macedonia and, "when Bosphor dying patient, who was on his death bed", would establish control over them. Monarchist circles in Sofia, Belgrade, Athens, joins in the Macedonian issue, not so much to liberate populations Slav-Macedonian, Serbian and Greek European Turkey, than to fulfill their aspirations against the invading Macedonian Albanian territories, which had a important strategic position, controlling the roads from the Danube to the Aegean and the Adriatic, through the "Roud Egnatia", the Aegean to the East. They took advantage of the fact that Macedonia did not exist as a separate administrative-territorial unit of the Ottoman Empire and occupied by a single measure ethnic-national. The interventions of the Balkan states and Great Powers on the Macedonian issue directly affects the national interests of the Albanian people and threaten the integrity of its territories. Occupying the same aspirations continued to be fed by the ruling circles of Serbia and Greece, who also covet to invade Albania and Macedonia. Meanwhile, the major European, especially Russia, Austria-Hungary and Italy, though aspiring to establish control over the Balkan possessions of the Ottoman Empire in particular on Albania for a long time had to follow preserve policy of status quo Ottoman Empire. This policy was seen as a tool that will be maintained, even temporarily "balance" between them in the struggle for influence in the Middle East and in particular Turkey's European possessions. Simultaneously, the safeguard of this status was concerned was Germany which opposed any sharing project areas held by the "status quo" she wanted to avoid a confrontation with a Great Power.

1. Russia as an interested party to extend its influence in areas held by the status quo, was engaged in the Far East, and prefers to maintain the status-quo in the Ottoman Empire.

2. Austria-Hungary, in turn require occupying a good part of South-Western Balkans, it utilized quite well preservers period of status quo, to further strengthen its position in Albania.

3. Italy, which is the same as Austria-Hungary was working to expand to Albania's Adriatic coast of the Ionian occupying a key point in the Otranto channel and for conveying respect at the time the status quo in the Ottoman Empire. (Historia e Popullit Shqiptarë II. 2002 fq 261)

\section{Italian expansionist}

De Rada was the first "Arbrech" denounced the risk of Italian expansionist aims, which exposed so strict, showing fare way. In the "Fiamuri" newspaper article "Albania and Italian temporary" stand out from the press on 20 November 1885, he wrote:

"By joining the Italian provinces interim statement of that part, which took over the reins of the union appears and goes on display a newly expressed desire to put the foot on the Albanian coast, and a fear that Austria will quickly descend among the banks and to take the Italian sun, will prevent that stretches from the East. " (De Rada.1979 fq 173).

Efforts of the Great Powers and the Balkan peoples who were against the creation of an Albanian state or principality went to Turkey's stature, but in fact the Turkish government was not able neither choose nor to prevent the intervention of the Great Powers. Austria-Hungary and the Kingdom of Italy and presented himself as "factors" critical to the map of the Balkans. Their attitude determined entirely by expansionary considerations, from the purely political interests, economic and territorial. Both countries sought might take the Balkans by providing a strong foundation in Albania; they were concerned that the Albanian coast not to fall into the hands' of Serbia or Greece behind which stood Russia, France and England. Besides Austria tried this coast not to fall either in the hands' of Italy, but Italy does not like to see on this coast as Austria. (Frashëri $1957 \mathrm{fq} 5$ ) In the framework of this policy, they would not allow Albania to break away from the yoke of the Ottoman unbearable and intervene immediately at Gateway High against Albanian liberation uprisings. But on the other hand, predicting the status quo in Eastern Europe cannot be long, each of them trying to create sound base in the Balkan peninsula, so that when overthrown the Ottoman Empire, disclose themselves benefits 
political and territorial. But in this case, none of them indicated, as for the future, sympathetic to the Albanian question. Tsarist Russia did not hide its program to splinter between Serbia, Albania, Bulgaria, Greece and Montenegro, so that through them to prevent the strengthening of the positions of Austria-Hungary in Eastern Europe and ensure its imperialistic influence growth in this sector. Austria-Hungary was principally against fragmentation in Albania in favor of the allies of Russia, but in practice it was intended to introduce all Albanian territories under its control. Also Italy, although weaker than the other powers, coveted invade Albania, and to provide a bridge crossing the Balkans.( Lito. 1979 fq 140).

Negative attitude towards the Albanian issue also held three Great Powers, France, which supported the Russian programs, Germany meant carrying Austro-Hungarian side, while England was trying to maintain an arbitrary position which was not in favor of the Albanian question. Ignorance of Albanian nationality from the Turkish government went seven Balkan states governments. Albanian territory regarded by their Turkish territory which would be subject to disintegration when the time comes. Albanian patriots (Xoxi.1983 fq 17) who understand the time in which the vortex is tumble Ottoman Empire, found face a greater risk of fissure Albanian territories gave a push war Albanian people to stand up and to demand their rights, They sought an autonomous Albania and were against fissure ethnic Albanian territories. In the years 1900-1908 increased demands for the press, as a result of cultural and political development of life itself the Albanian people. Among these bodies also excelled newspaper "Drita" Shahin Kolonja, published in Sofia Bullgari during the years 1901-1908, which became a political grandstand events in Albania at the time and defensive war demands of the Albanian people for national liberation. Another paper, which was the subject of conversation through correspondence, excelled newspaper Nikola Naço "Shqiptari", the newspaper attract enough attention to the outside world as a representative of a wide range of political opinion Albanian readers. She denounced the Powers occupying goals to the detriment of the country. Other papers that testify to the events in Albania was "Independence Albania" it was published in Romania in Turkish, Italian, French, the first number appeared in Naples on April 15, 1901. (Kondo.1988 fq 156) Its purpose was to make known the Albanian issue in the international arena, and to strengthen national consciousness opinion. Italy and Austria-Hungary, together with other Balkan states; development and strengthening of the Albanian national consciousness was a serious loss to their policy. To assist in raising the national consciousness, and to further strengthen Albanian individuality as a nation; Renaissance used history as a powerful tool in the service of the Albanian question, and also to attract the attention of European opinion. Albanian patriots understood that the great powers of the time played a big role in the international arena and their word in favor or against the Albanian demands had special significance. Renaissance in accordance with the time of the circumstances identified ways in which the Albanian people, as its Balkan neighbors, would come to form its national state united. (Akte të Rilindjes Kombëtare.1978. fq.8) Organization of the Albanian Renaissance thought in both forms of autonomy and independence. They are always conceived as two-step resolution Albanian issues closely related to each other. Administrative-territorial autonomy create opportunities to rise up the political and legal institutions and social and economic structures, which will serve as a support for an independent state order, which will be located just create the conditions. They see autonomy as a measure that can be reconciled with the status quo policy of the Ottoman Empire followed by the Great Powers. Albania's organization as a separate autonomous state entity, even within the Ottoman Empire also would prevent the risk of its identification with the Empire, when it fall apart and her possessions were divided among the Balkan states. With the promulgation of the constitution by Abdulhamid II on 23 July 1908 raised the premise for all the oppressed peoples of the Ottoman Empire for autonomy and democracy. (Naska. $1987 \mathrm{fq}$ 59) Despite numerous promises everything remained just written on paper, Albanian demands were ignored again. Albania's political struggle to secure administrative autonomy remained the same as had been earlier. (Prifti. $1968 \mathrm{f} 185$ ). One of the leaders of this trend was Ismail Kemal, who, like other leaders of autonomous movement consistent war against Young Turks. Young Turk stringent reaction against Albanians, create a condition slowly revolution countrywide. He felt particularly in the "vilayet of Kosovo", which followed anti-ottoman uprising in the spring of 1910. The beginning of the uprisings in Kosovo vilayet was associated with increased political and diplomatic activity abroad patriotic circles. Ismail Kemali and other members of the Albanian patriotic power revolution after being convinced that the Ottoman government had decided not to make concessions to their co-patriots, determined to turn the Great Powers and raise international public opinion defended Albanian insurgents, Taking advantage of the situation in Albania, the governors of Rome proved to be more engaged with Albanian leaders, promising them material assistance to gain self, provided that they supported Rome's imperial goals in the Adriatic region. (HHStA, PA, A. Raport consul Kviatovski 21 december 1910). It is understood that these promises Rome sought to attract Albanians turn and then exert its influence to the Albanian question. Albanian leaders who followed policies both Rome and Vienna both were intended for the invasion of Albania, they used well the disagreement between the two powers to distract from both sides any support for this cause. Vienna itself even began to doubt that the Albanian leaders in their relations with Rome exploit contradictions between Austria-Hungary and Italy 
regarding their attitude towards Albania. In late 1910 and early 1911, Ismail Kemali along with other patriots began preparations for a new uprising, at the request of administrative autonomy. They were meant to give an uprising overall national character and to create a single center leadership. Nikola Ivanaj initiative Themistokli Gërmenji and others, was formed in Bari Albanian uprising, which established ties with the Albanian colonies of exile and intelligence committees operating within Albania.

11-es rebel movement that erupted in Albania although press became the main foundation of the next general uprising; she pointed out the will of the Albanian people, also revealed the weakness of Turkey, and questioned holding the status quo in the Balkans. After the annexation of Tripoli by Italy, the principle of territorial integrity of the Ottoman Empire was not respected. Ignorance of Albanian nationality increase risks for partition of Albania. Turkish territorial division (which was part of Albanian territory) from the Balkan powers will not be rejected by Russia, but the question arise: Would a Russian interference in their support? Russia's intervention in the Balkans would simply victim of its intervention. The creation of a Greater Serbia or a Greater Greece would lead to armed struggle with Austria-Hungary, which had interest's expansion to Albania. Also would support Germany and neutrality of France and England. She would never allow that as a Great Power or Balkan expansion towards the Albanian port which would bring its isolation therefore the Adriatic. (Poincare, 2005 fq 196) While the French government in September 1912 presented a deal backed by the British government and the Russian imperial government, to safeguard peace and keeping of status quo in the Balkan Peninsula qualified "than just a collective action of great powers can prevent serious events, which threaten peace and balance in East European countries. Consequently, the above governments intend to submit for approval by the German imperial government and the imperial government of Austro-Hungarian royal following measures:

1. Powers to intervene at the same time and as soon as the government of Sofia, Belgrade, Athens and Cetinja to advise not to take anything that might disturb the peace or affect the status-quo in the Balkan Peninsula.

2. If their advice is not heard, the powers will immediately combine their efforts to limit war and to end it. They claim particularly troubling states not to hope, from a possible victory, for no earthly benefit.

3. In the event that the continuation of the events will the need to use more drastic means, such as military or naval demonstration, will be used as the powers to organize collectively.

4. At the same time that they are performing mastication of paragraph 1, the powers would intervene at the Porte to advise make in life, without delay, administrative reforms, which legally require the Christian populations of the peninsula Balkan.

On October 7, (Ivetic, 2006. p.70) after much effort from the French government accepted the proposal by all the Great Powers. European intervention came too late as the Balkan state did not accept. In early October 2012 spread the word for peace signed between Italy and Turkey in secret to not trigger any reaction to the Balkan powers which those in secret had long been prepared for total war against the Porte High.

While Turkey does not recognize potential would accept an ultimatum from the Balkan states, while on the contrary, was keen to give more serious securities powers on the issue of reform. Discussion of risks contained reforms duration risk; and if Europe delayed even more, fire will guzzle everything before they reached Firefighters. Montenegro driven by Russia and possibly Italy protested against the agreement reached by the Great Powers, as relations with Turkey were not regulated and required a solution under the gun. On October 8, Montenegro declared war on Turkey. Italy had increased pressure on Turkey and deadline to sign peace was established 15 October. Efforts to reduce our already were futile plan "Balkan League" had taken life. Balkan fate depended not from Europe. He was in the hands of the Turkish armies and allies. On October 15, Turkey accepts the conditions imposed by Italy on the same day Balkan states rushing to declare war on Turkey. End a war. Start another war.

\section{Conclusion}

History of the Balkans in the late nineteenth century and early twentieth century was characterized by some major movement.

1. The continuing decline of the Ottoman Empire

2. Awakening nations.

3. Great Powers interventions to maintain their political and economic strategic interests in the Balkans.

4. Separation of zones of influence.

The development of these "movements" is determined by several factors: They are under the constant influence of long-term Italian and Austro-Hungarian expansionist policy. But they are the people of the Balkans who have the burden of these major changes. The idea of creating an autonomous or independent Albanian state not viewed favorably, even 
greater damage caused war Albanian people for national liberation was the attitude of the neighboring countries, which were against the creation of an Albanian state.

\section{References}

(Puto. 1987) =A.Puto Probleme të Pavarësisë së Shqipërisë Tiranë 1987.

(Mile.1986)=Ligor Mile. Shqipëria në vitet ë Lidhjes Shqiptare të Prizrenit vell II Tiranë 1986.

AMAE.CP Embassy of France in Instanbul . Volume 434 .fl $177 \mathrm{r} 178 \mathrm{rv}$

AMAE.CP Embassy of France in Instanbul . Volume 434 .fl 155-167 rv

AMAE CD Embassy of France in Instanbul. Volume $435 \mathrm{fl} 130 \mathrm{rv}-137 \mathrm{rv}$.

Historia e Popullit Shqiptarë II. Botimet Toena Tiranë 2002.

(De Rada 1979)= Jeronim De Rada " Jeta dhe veprat" Tiranë 1979.

(Frashëri 1957)= Kristo Frashëri. Shpallja e Pavarësisë së Shqipërisë. 28 Nëndor 1912. Tiranë 1957.

( Lito. 1979)= Zana Lito. Trajtimi i problemeve politike të rilindjes nga gazeta "Shpnesa e Shqypnis" (1905-1908). Studime historike I Tiranë 1979.

(Xoxi.1983)= Koli Xoxi. Ismail Qemali(Jeta dhe Veprat)Tiranë 1983.

( Kondo.1988)= Ahmet Kondo. Aspekte të Lëvizjes Kombëtare. Tiranë 1988.

(Akte të Rilindjes Kombëtare Shqiptare 1978)= Akte të Rilindjes Kombëtare Shqiptare 1878-1912. Tiranë 1978.

(Naska. 1987 fq 59)= Kaliopi Naska. Ismail Qemali. Në lëvizjen kombëtare shqiptare. Tiranë 1987.

(Prifti. 1968 f185)= Kristaq Prifti. Lëvizja politike-kulturore në Shqipëri në pragun e Kongresit të Manastirit,në, studime historike" nr 4, $1968 \mathrm{f} 185$.

HHStA, PA, A. Raport consul Kviatovski 21 dicember 1910.

(Poincare, 2005 fq 196)= Raymond Poincare, "Lufta e I dhe e II Ballkanike si dhe Konferenca ë Londrës (1912-1913) Botim Logos-A Shkup 2005.

(Ivetic, 2006. p.70)=Egidio Ivetic, Le guerre balcaniche, il Mulino - Universale Paperbacks, 2006. 
